Research Paper

\title{
Presenting the Prospects for Ropeway Implementation as a Public Transport Mode, the Case of Moscow
}

Author Andrew BORISOW, National Research University Higher School of Economics Institute for Transport Economics and Transport Policy Studies, Centre for Transport Modelling, Russia aaborisov@hse.ru | itetps.hse.ru; Russian Federation

\begin{abstract}
Modern technological advances in transport engineering and transport construction expand tools available to a transport planner: previously considered purely niche, "exotic" transit modes begin claiming to be full-fledged urban public transport varieties. One of those are aerial ropeways. The paper analyses international experience of this technology as a mass transit component used in urban environments. We suggest factors can influence decision making in favour of aerial cableways as a form of public transport. Within the proposed methodology, we identify pairs of adjacent districts where cableways could be sufficient as an element of an intermodal transit system.
\end{abstract}

\section{Keywords}

Public transport systems, cable-propelled transit, aerial cableways, connectivity

\section{Introduction}

\subsection{Preface}

The issue of how modern cities are organized and developed is one of the most pressing nowadays. Indeed, the share of urban population in the world has been already above $54 \%$ (55.3\%), whereas by 2050 the percentage tend to be around $66 \%$. Currently about $74 \%$ of Russian population lives in cities, and by 2050 this figure should exceed $80 \%$ (UN, 2018). At the same time, Moscow population in 2018 was estimated in about 12.5 million inhabitants (Rosstat, 2018). The importance of competent transport planning in such a city as Moscow is without any doubt. In fact, the capital of Russia carries the legacy of the USSR era, exposed in its' morphology and road network configuration: the mono-functionality of peripheral areas with a predominance of residential uses, while the proportion of the built-up area of the city allocated for streets and roads on the outskirts does not reach 10\% (Blinkin, 2018).

While it is clear that a permanent increase in the share of streets and roads in such circumstances would not be economically justified, Moscow tend to solve the accessibility challenge in various ways: one of them is the development of public transport system, its attractiveness. In terms of utility, the attractiveness of public transport for an individual could be considered as a function of time spent on the journey. Although this is far from the 
only variable describing attractiveness, it is however the most suitable for the planner in terms of an unambiguous assessment. Thus, the maximum level of utility would be achieved by minimizing the duration of time travelled. Obviously one's attitude to public transport as an alternative to a personal vehicle is rather impossible to interpret. However, it can be argued that the more choices and the higher the average speed of public transit are provided to the population, the greater is the probability of its attractiveness among citizens.

Fundamentally, planner's decision of a public transport mode on the section from point $A$ to point $B$ is based on various parameters, one of the keys when making such decisions is transport demand - in other words, the number of passengers moving daily from one location to another. Generally, classic urban transport modes (bus, tram, subway, etc.) are used for such objectives, depending on their carrying capacity. However, for urban planners there are much more restrictions like commissioning costs, operating expenses, existing settlement, and others. Hence, in some cases, standard urban transport planning tools cannot efficiently solve immediate problems. Solutions, previously considered narrowly applicable, may prove to be complementary to a modern city development agenda, complementing public transport network and assisting to solve a specific series of urgent issues.

In this paper, Moscow is considered as an example of a dynamically developing city with high intraday passenger traffic and typical post-Soviet cities' issues (see above). In the context of its' specifics, namely the low connectivity level, implementation of aerial cableways as an element of Moscow's public transport system is proposed, foremost, to increase the accessibility of neighbourhoods.

\subsection{Goals and Objectives}

In recent years, cable transport systems (cable-propelled transit) have been significantly improved in terms of technological applicability for urban transport and can currently fill a niche in the urban transport system, where traditional methods might be relatively less efficient. Moscow suffers from the problem of low connectivity - especially when it comes to peripheral areas of the city. The issue is due to the poor development of the road network, in particular, lack of overpasses through railways and bridge crossings over water barriers, as well as the presence of blocked areas (usually industrial zones) between neighbouring areas. Low connectivity, in turn, generates an extremely high rerun rate, amounting to 1.7 in Moscow versus 1.2-1.4 for cities with a developed street network. It is clear that this circumstance negatively affects the existing public transport, total time spent on journeys and the quality of life in general (Ingrid E. Schneider, 2013).

The object of the research is aerial cableway passenger systems, while the subject is the possibility of expanding the typological spectrum of urban passenger transport due to the implementation of the aerial ropeways as a type of public transport on the example of Moscow.

Basic hypothesis suggests the need to establish direct transport links between isolated areas of the city of Moscow, while the solution could be met by incorporating modern aerial ropeways into urban transport systems. Thus, the purpose is to propose an evaluation methodology corresponding to connectivity estimates of Moscow districts. The results of the analysis show for which areas of the city implementation of aerial cableways as an element of the public transport system is appropriate and valid. 


\section{Ropeways in urban transportation practice}

\subsection{Technological features}

The paper deals exclusively with aerial cableways. Such decision follows from the specifics of this type of transport, namely: capital and operating expenditures, low terrain requirements for development and construction. While describing the cableways, terminology adopted in the community of urban planners - The Gondola Project - is used. Thus, it is considered hereinafter to be called CPT or Cable-Propelled Transit.

Modern practice of CPT successful use worldwide in urban environments is due to a significant improvement in technical characteristics of these systems. First, manufacturers have significantly improved the CPT speed performance compared with the predecessor used in cities. To date, this type of transport is able to reach speeds above $40 \mathrm{~km} / \mathrm{h}$ (Doppelmayr / Garaventa_1), while the average speed of standard monocable systems exceeds $20 \mathrm{~km} / \mathrm{h}$ (Marocchi, 2015). Thus, according to this indicator, CPT can compete with some traditional types of urban public transport (Griškevičienè, et al., 2006), (Madejski, 2005). Secondly, modern CPT types have sufficiently high carrying capacities, comparable to bus routes. At the same time, infrastructure construction and rolling stock purchases, as well as operating costs, are also comparable to corresponding capacity systems.

Indeed, aerial cableways can effectively complement urban mass transit, especially within the existing development. However, it is important to note that when considering the issue of CPT implementation in the city, it is necessary to understand that this system is not an alternative to existing types of urban public transport, but serves as a local addition to existing system in current planning conditions.

Further, we consider the existing types and technical features of aerial ropeways, as well as quantitative estimates of its application - in terms of costs, safety, transport indicators, tariffs and indirect effects.

\subsection{CPT types}

Features of the traction device, passenger capacity, speed, and resistance to climate conditions - all this features distinguish cableways applicable in urban environments. In total, there are five main types of top-supported cableway systems: (1) MDG, (2) BDG, (3) TDS/3S, (4) Funitel, (5) Aerial tram, (6) Pulsed gondola. Indeed, each of them are well described, although either in most publications, we observed discrepancies in technical data, or absence of their full description was found. This paper illustrates an attempt to unify that data and depict it (Table 1) on the grounds of several cases.

1) MDG or mono-cable detachable gondolas

Cableways with detachable gondolas are the most common type of CPT as part of public transport systems. Gondolas move along a single traction-carrying cable, which is turned around at the end stations and is driven by a traction wheel. At the station, cabin grip disengages suspension cable, and its further movement performs using roller guides.

2) BDG or bi-cable detachable gondolas

Same as MDG, but traction and carriage are divided between two cables.

3) TDS / 35 or tri-cable detachable gondolas 
Operating with two steering and one traction cables, this kind of CPT offers significant throughput growth in terms of operating speed, resilience and passenger capacity. The rest repeats two previous types.

4) Funitel

A special characteristic is the design feature of two installed loopback cables, performing as a traction-carrying function simultaneously for opposite directions.

5) Aerial tram

A classic aerial tram consists of two independent stationary guiding cables for each carriage and one looped traction cable. The cab itself has high passenger capacity, much higher than previously described systems - from 50 to 200 people. The key feature is the maximum speed indicators among the CPTs. Aerial trams are able to reach speeds up to $43.2 \mathrm{~km} / \mathrm{h}$.

6) Pulsed gondolas

This type's peculiarity is in non-trivial installation solution: several small-sized gondolas are set in close proximity to each other, thus a group cableway can be characterized as a combination of classic MDG and aerial tram. In terms of speed, it is comparable to MDG / TDG, but inferior in carrying capacity to all of the systems above - up to 1000 pphpd (Jacobs, 2016). Hence, it is least disposed for public transport uses.

Features and cities where these systems operate are indicated in Figure 1.

\begin{tabular}{|c|c|c|c|c|c|c|c|c|c|c|c|}
\hline City & Opening & Type & $\begin{array}{l}\text { Length, } \\
\text { meters }\end{array}$ & $\begin{array}{l}\text { Cabin } \\
\text { capacity }\end{array}$ & $\begin{array}{l}\text { Number of } \\
\text { cabins }\end{array}$ & $\begin{array}{c}\text { Operating } \\
\text { speed, } \mathrm{km} / \mathrm{h}\end{array}$ & $\begin{array}{c}\text { Peak } \\
\text { headway, } \\
\text { seconds }\end{array}$ & pphpd & $\begin{array}{l}\text { Tariff, US } \\
\text { dollars }\end{array}$ & $\begin{array}{l}\text { Ticket menu } \\
\text { integration }\end{array}$ & $\begin{array}{l}1 \mathrm{~km} \text { cost, } \\
\text { mio US } \\
\text { dollars }\end{array}$ \\
\hline New York & 1976 & Aerial & 3100 & 78 & 2 & 26 & $7,5 \mathrm{~min}$. & 1000 & 2,75 & \multirow{3}{*}{ yes } & $8,6^{*}$ \\
\hline Portland & 2006 & Tram & 1027 & 126 & 2 & 35,4 & $5 \mathrm{~min}$. & 2028 & 4,7 & & 55,5 \\
\hline $\begin{array}{l}\text { Medelin } \\
\text { (Line K) }\end{array}$ & 2004 & \multirow{3}{*}{ MDG } & 2072 & 10 & 93 & 18 & 12 & 3000 & 0,75 & & 11,58 \\
\hline $\begin{array}{l}\text { Nizhny } \\
\text { Novgorod }\end{array}$ & 2012 & & 3661 & 10 & 28 & 18 & 60 & 1000 & 1,2 & no & 4,21 \\
\hline London & 2012 & & 1100 & 10 & 36 & 21,6 & 60 & 2500 & 4,67 & yes & 72,57 \\
\hline Hong Kong & 2006 & $\mathrm{BDG}$ & 5700 & 17 & 112 & 27 & 18 & 3500 & 9,43 & \multirow{2}{*}{ no } & 16,75 \\
\hline Coblenz & 2010 & TDG/3S & 890 & 35 & 18 & 19,8 & 34 & 3700 & 8,41 & & 13,35 \\
\hline
\end{tabular}

Figure 1. Author's estimates, (Alshalalfah, et al., 2012), (Dale, et al., 2013), (The Gondola Project, 2011)

\section{* Reconstruction carried out in 2010}

\subsection{Comparative evaluation}

According to the analysis of reviewed CPT systems, as well as the analysis of the calculated technical and economic indicators, it is possible to compare the CPT with the classical urban mass transport. Figure 2 presents a quantitative comparison estimates for CPT systems and prevalent public transit modes.

As a result, in relation to carrying capacity and capital expenditures, cableways are comparable (conditionally) to bus and tram. When comparing the cost per kilometre, CPT types as well as the number of cabs allowance is essential. Obviously, many factors that might affect the final project costs cannot be fully disclosed here (materials, financial plans were not disclosed). Remarkably, delta between the capital costs is significantly less alters than bus and tram analogues within the capacity range (Carlet, 2017). 


\begin{tabular}{|c|c|c|c|c|c|c|c|c|c|c|}
\hline Transit mode & RoW & $\begin{array}{c}\text { Operating } \\
\text { speed, } \\
\mathrm{km} / \mathrm{h}\end{array}$ & $\begin{array}{c}\text { max. } \\
\text { speed, } \\
\mathrm{km} / \mathrm{h}\end{array}$ & $\begin{array}{l}\text { Passenger } \\
\text { capacity } \\
\text { (3,5pax/m2) }\end{array}$ & $\begin{array}{c}\text { Passenger } \\
\text { capacity } \\
\text { (5pax/m2) }\end{array}$ & $\begin{array}{l}1 \mathrm{~km} \text { cost, } \\
\text { US dollars* }\end{array}$ & pphpd & max. pphpd & $\begin{array}{c}\text { Number of } \\
\text { cars }\end{array}$ & $\begin{array}{c}\text { max. } \\
\text { Number of } \\
\text { cars }\end{array}$ \\
\hline Tramline & C & 23,1 & до 30 & 197 & 430 & $3-10$ & 7880 & 20000 & 3 & 5 \\
\hline BRT & B & 26 & до 40 & 100 & 250 & $1-10$ & 4000 & 12000 & 1 & 2 \\
\hline LRT & B & 38,5 & до 70 & 200 & 750 & $5-50$ & 8000 & 36000 & 5 & 7 \\
\hline Subway & A & 48 & до 80 & 1200 & 2632 & $40-130$ & 48000 & 70000 & 4 & 8 \\
\hline Urban rail & A & 53,6 & до 90 & 2043 & 4700 & $40-150$ & 81720 & 90000 & 6 & 10 \\
\hline CPT & $A$ & 21,6 & up to $48^{\star *}$ & up to $8-10$ & up to $230^{* *}$ & $5-8$ & 1800 & 4000 & 1 & 1 \\
\hline
\end{tabular}

Figure 2. Author's estimates, (Alshalalfah, et al., 2012), (Jacobs, 2016), (Marocchi, 2015)

* Includes all capital costs: rolling stock and other infrastructure facilities

** Peak operational speed values at the spans, as well as the maximum passenger capacity are calculated for aerial tram, while the maximum passenger capacity for TDS/3S reaches 6000 pphpd

By type of application, the vast majority of CPTs operating in urban environments are the MDG family, which is associated with considerably lower costs and to relatively high capacities. Most of these systems are installed as an alternative to complex transport infrastructure (tunnels, bridges, etc.) due to the terrain-challenged relief and / or within existing development and environmental management. Aerial trams are established to connect areas with a stable predefined transport demand. All that systems have never been tested at their peak capacities (6 000 pphpd or even more) and considering a CPT as an alternative to metro or LRV is not entirely correct, at least for transport safety reasons. Hence, we do not consider CPTs as trunk lines, presuming on the contrary to be an addition to feeder transport and solving local problems.

In accordance with the above-mentioned features the paper proposes a methodology for assessing the city of Moscow to CPT implementation.

\section{The Research}

\subsection{Context}

Moscow is of the greatest interest to consider any transport innovation prospects for many reasons. The total daily passenger traffic by all mass transit types is about 18 million passengers. The cumulative annual budget expenditures is about 250 billion roubles (approximately \$4 billion). Both numbers are among the highest compared to other global cities (Moscow DoT, 2017). At the same time, a number of local transport problems generated by low connection density and road network connectivity are still unsolved.

Below, we identify poor connected districts and offer a solution using CPT. Additionally, indeed over the past year two cableways appeared in Moscow, none of them integrated in mass transit system.

\subsection{Approach}

The paper proposes an approach that identifies areas suffering from poor connectivity and continuous blocked borders. For this it is necessary to set a few exogenous parameters. In accordance with the above-mentioned features the paper proposes a methodology for assessing the city of Moscow to possible CPT implementation. All administrative districts within the Moscow Ring Road are chosen, since the main objective is to improve the existing 
transport network intensively. The idea is to identify neighbouring districts with at least one common border, the direct transport links between which are absent and the border itself represents a continuous barrier - area where transport infrastructure construction is obstructed or impossible. These "barrier areas" include natural reserves, urban forests, parks, water bodies, cemeteries, industrial zones, port zones, defence facilities, incinerators, railway transport infrastructure.

Than all these objects are displayed and clipped by districts' boundaries, represented as a buffer zone around linear objects districts and 400 meters in diameter (Figure 3). The parameter is defined as the maximum public transport access level to commercial and residential specified by Moscow Government (Regional Ordinances, 2015). The results show continuously blocked boundaries, apart from areas within the T1-T4 urbanization zones in accordance with current classification (means, predominantly unsettled areas). Continuity is measured as orthogonal display of selected areas in the form of a continuous curve.

The next step is to overlay the road network metro and tram lines (Figure 4). Now we introduce a pairwise connectivity assumption: two randomly selected neighbouring areas with at least one blocked border considered to be unsatisfactory connected under the following conditions:

- the topological distance along the road network between these areas is zero;

- there is no metro line, the stations of which are in the body of each considered district in pair;

- there is no tram service between the districts.

The concept of area body is introduced exogenously and defined as a part of an administrative district, except for territories within 100-meters buffer zones around district borders. The buffer is taken in accordance to Regional Ordinances, meant the interchange length between public RoW C and RoW B transit stops (bus, tram) and RoW A (subway, urban rail). A set of satisfying districts are shown in Figure 5.

\subsection{Final assessment}

Implying intensive development, we are based on (1) filling existing gaps and (2) connecting blocked areas with public transport network. The decision makes it possible to expand the transit choice for selected districts having trunk links with Moscow urban core, but without local inter-district correspondence capabilities. This leads to over mileage and travel time loses.

We impose a condition: each district pairs must have at least one metro station within its' body, not belonging to the same line.

Thus, we form a set of neighbouring areas with a common continuous barrier passing along the adjacent border and the absence of straight-line inter-district transport links. These pairs could relate to CPT use, which in turn could be integrated into public transport network. Since our main purpose is not to trace exact routes, we define the potential length of these systems as the minimum air distance between metro stations of each chosen pair. At the same time, we introduce the "Realistic condition" - a distance limit should be no more than 4000 meters (from Figure 1, "length"). The new sample is presented in Figure 6. 


\section{Layer 6}

District boundaries within 200 meters buffer zone

\section{Layer 5}

River zones amd waterbodies

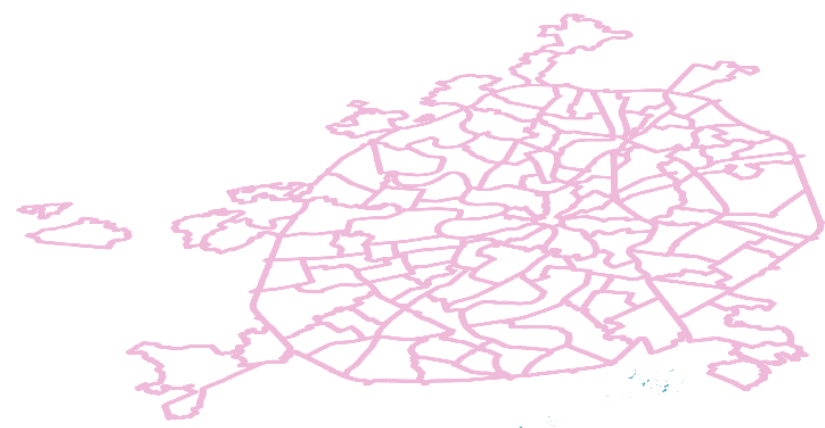

Layer 4

Railway tracks within 100 meters buffer

\section{Layer 3}

Industrial zones, brownfeeld areas

Layer 2

Conservation zones, urban forests, parks

Layer 1

District boundaries within the old Moscow borders

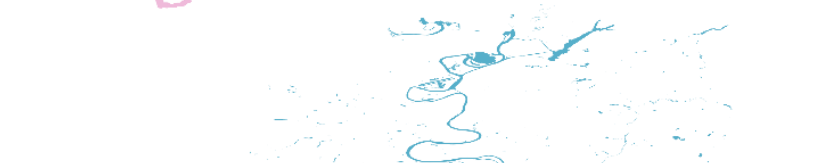



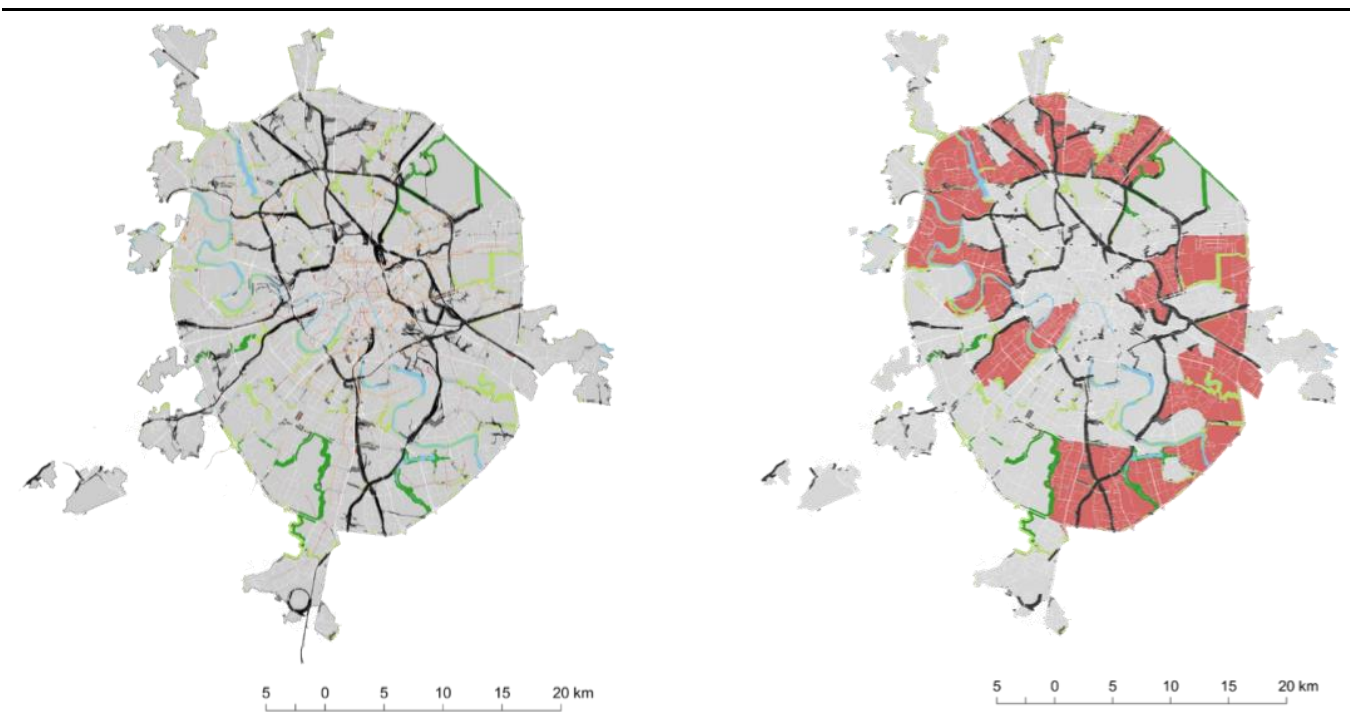

Figure 4, 5. Initial set selection. Author's model

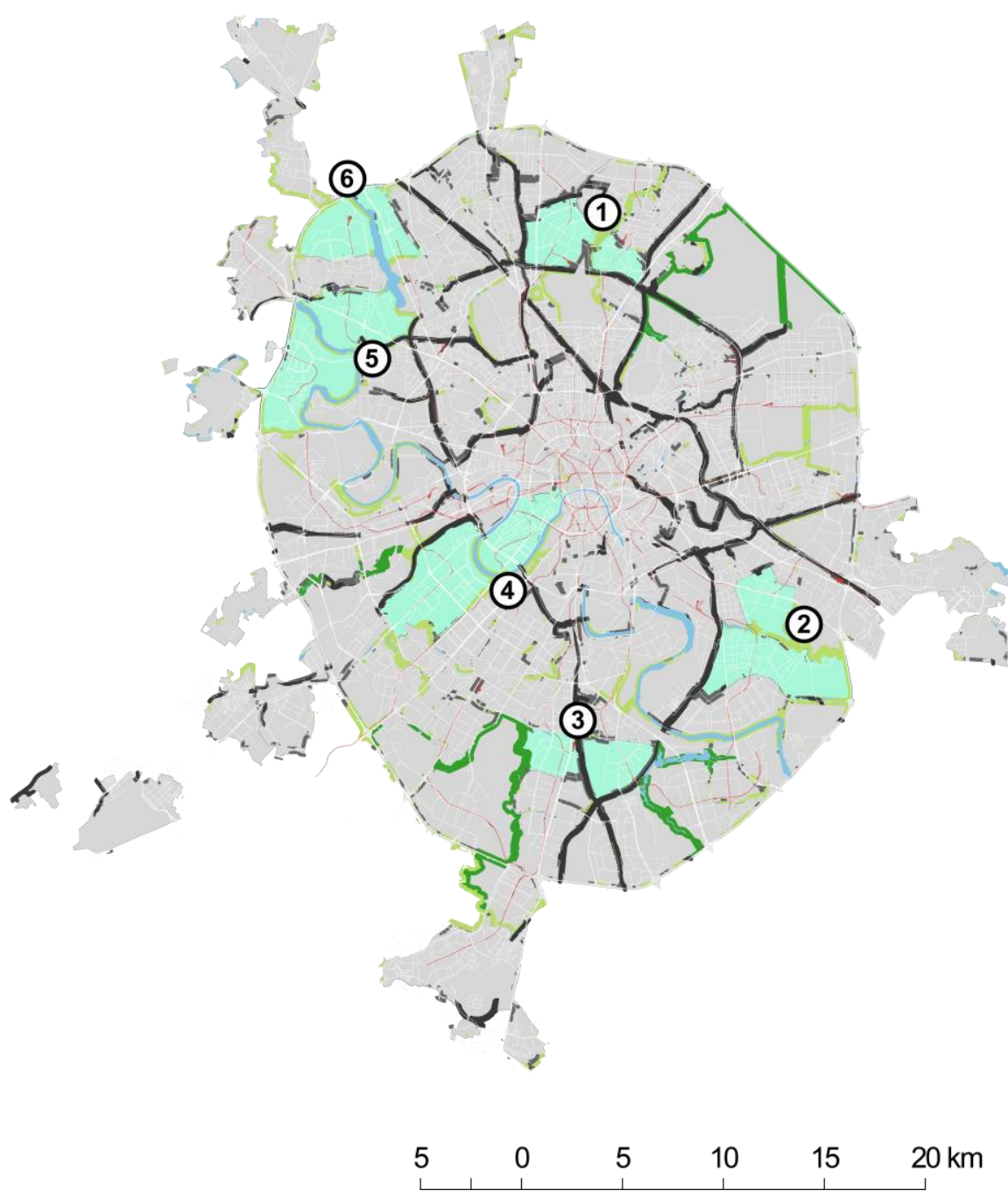

Figure 6. Final sample. Author's model 
The selected six pairs are also presented in Figures 7, 8 and a comparative analysis results with satisfactorily connected pairs of areas in terms of overmileage. In addition, ODs for the six pairs were analysed. It was considered cumulative, from the nearest terminal station, using Moscow Metro O-D Matrix (granted on request).

As it is shown, the least transport demand is imposed on the last pair (Figure 9). It is an unexpected result, since these districts are considered for the cable car construction (Interfax, 2018); moreover, the source predict passenger traffic of about 19 thousand passengers per day.

For that reason, a link analysis using traffic macro model was additionally carried out. But this also did not produce results like indicated figures. Appendix illustrate the total demand for inter-district correspondences (about 200 cars per hour).

Probably the calculation should be carried out using the multimodal (rather than traffic) simulation. However, such calculations are beyond the scope of this study.

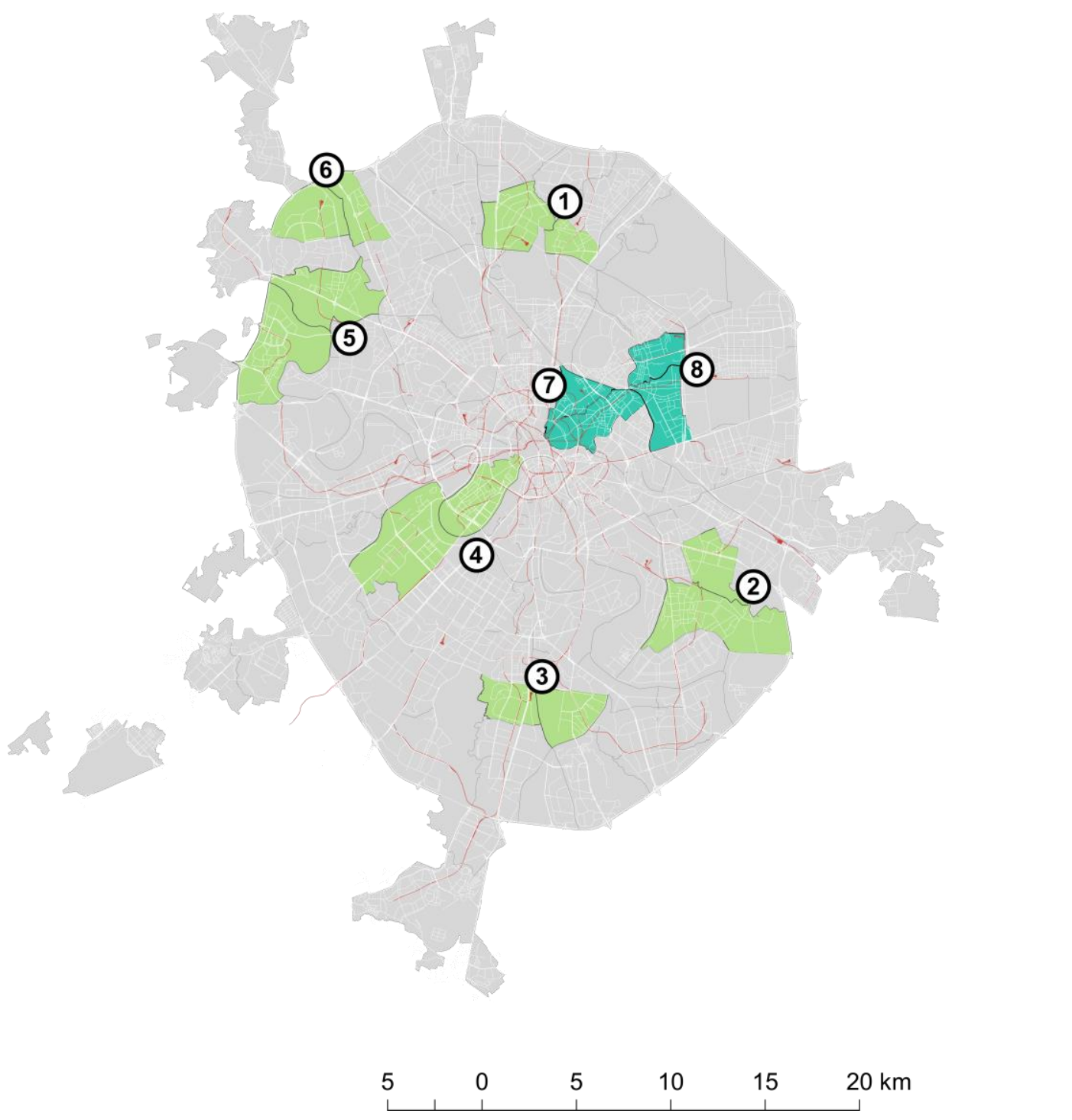

Figure 7. Six considered + two compared (7 and 8) districts. Author's calculations 


\begin{tabular}{|c|c|c|c|c|}
\hline & Pairs & $\begin{array}{l}\text { Aerial distance between } \\
\text { metro stations, } \mathrm{km}\end{array}$ & $\begin{array}{l}\text { Time travelled by public } \\
\text { transport, min }\end{array}$ & $\begin{array}{l}\text { Time travelled by } \\
\text { individual vechicle }\end{array}$ \\
\hline \multirow{7}{*}{ 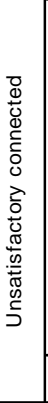 } & 1 Otradnoe - Sviblovo & 3,1 & 29 & 12 \\
\hline & 2 Kuzminki - Lyublino & 3,32 & 32 & 16 \\
\hline & $\begin{array}{l}3 \text { Tsaritsyno - Chertanovo } \\
\text { Severnoe }\end{array}$ & 3,32 & 28 & 17 \\
\hline & 4 Ramenki - Khamovniki & 3,51 & 33 & 22 \\
\hline & $\begin{array}{l}5 \text { Strogino - Pokrovskoe- } \\
\text { Streshnevo }\end{array}$ & 3,3 & 33 & 20 \\
\hline & $6 \begin{array}{l}\text { Severnoe Tushino - } \\
\text { Levoberezhniy }\end{array}$ & 2,59 & 47 & 20 \\
\hline & average & 3,19 & 34 & 18 \\
\hline \multirow{3}{*}{ 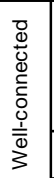 } & $\begin{array}{ll} & \text { Preobbrazhenskaya ploshad - } \\
7 \text { Semenovskaya }\end{array}$ & 1,49 & 14 & 6 \\
\hline & 8 Basmanny - Krasnoselsky & 1,13 & 10 & 9 \\
\hline & average & 1,31 & 12 & 8 \\
\hline
\end{tabular}

Figure 8. Comparative analysis. Author's calculations

\begin{tabular}{|c|c|c|c|c|}
\hline Districts (Direct route) & Metro stations & pphpd, cumulative & Districts (Reverse route) & pphpd, cumulative \\
\hline Otradnoe - Sviblovo & Otradnoe - Sviblovo & 14 & Sviblovo - Otradnoe & 37 \\
\hline Kuzminki - Lyublino & Kuzminki - Lyublino & 93 & Lyublino - Kuzminki & 123 \\
\hline $\begin{array}{l}\text { Tsaritsyno - Chertanovo } \\
\text { Severnoe }\end{array}$ & $\begin{array}{l}\text { Kantemirovskaya - } \\
\text { Yuzhnaya }\end{array}$ & 205 & $\begin{array}{c}\text { Chertanovo Severnoe - } \\
\text { Tsaritsyno }\end{array}$ & 174 \\
\hline Ramenki - Khamovniki & $\begin{array}{l}\text { Lomonosovskiy } \\
\text { prospekt - Sportivnaya }\end{array}$ & N/A & Khamovniki - Ramenki & N/A \\
\hline $\begin{array}{l}\text { Strogino - Pokrovskoe- } \\
\text { Streshnevo }\end{array}$ & Strogino - Tushinskaya & 65 & $\begin{array}{c}\text { Pokrovskoe-Streshnevo - } \\
\text { Strogino }\end{array}$ & 66 \\
\hline $\begin{array}{l}\text { Severnoe Tushino - } \\
\text { Levoberezhniy }\end{array}$ & $\begin{array}{l}\text { Planernaya - Rechnoy } \\
\text { Vokzal }\end{array}$ & 18 & $\begin{array}{l}\text { Severnoe Tushino - } \\
\text { Levoberezhniy }\end{array}$ & 19 \\
\hline
\end{tabular}

Figure 9. Passengers travelled (morning peak). Author's estimates, Moscow Metro OD-matrix

\section{Discussion}

The main feature of CPTs is a possibility of supplementing feeder systems, so public transport system multimodality could be enhanced.

We identified the basic principles that should be followed when deciding CPT use in the city. Proposed approach for Moscow evaluates the basis on which the straight-line connections creation between neighbouring but isolated districts is set. We determine such areas of the city. As a result, four pairs of districts are proposed (Figure 9).

According to the author's opinion, an important implementation component is the presence of positive visual qualities of the potential route. Proceeding from this subjective hypothesis, we found it possible to reduce the number of pairs to four, while excluding the OtradnoeSviblovo and Tsaritsyno-Chertanovo Severnoe. Thus, the decision could not only solve local transport problems, but also contribute to new attraction.

However, we are not claiming the unambiguity of our conclusions. On the contrary, one or another decision on transport infrastructure development may be based not so much on objective factors, such as passengers travelled or relative costs, depending more on political preferences. We tried to offer a very obvious and transparent connectivity assessment, 
bearing in mind CPT technical features and hence provided an opportunity to view the map of the city with a sober and unbiased look.
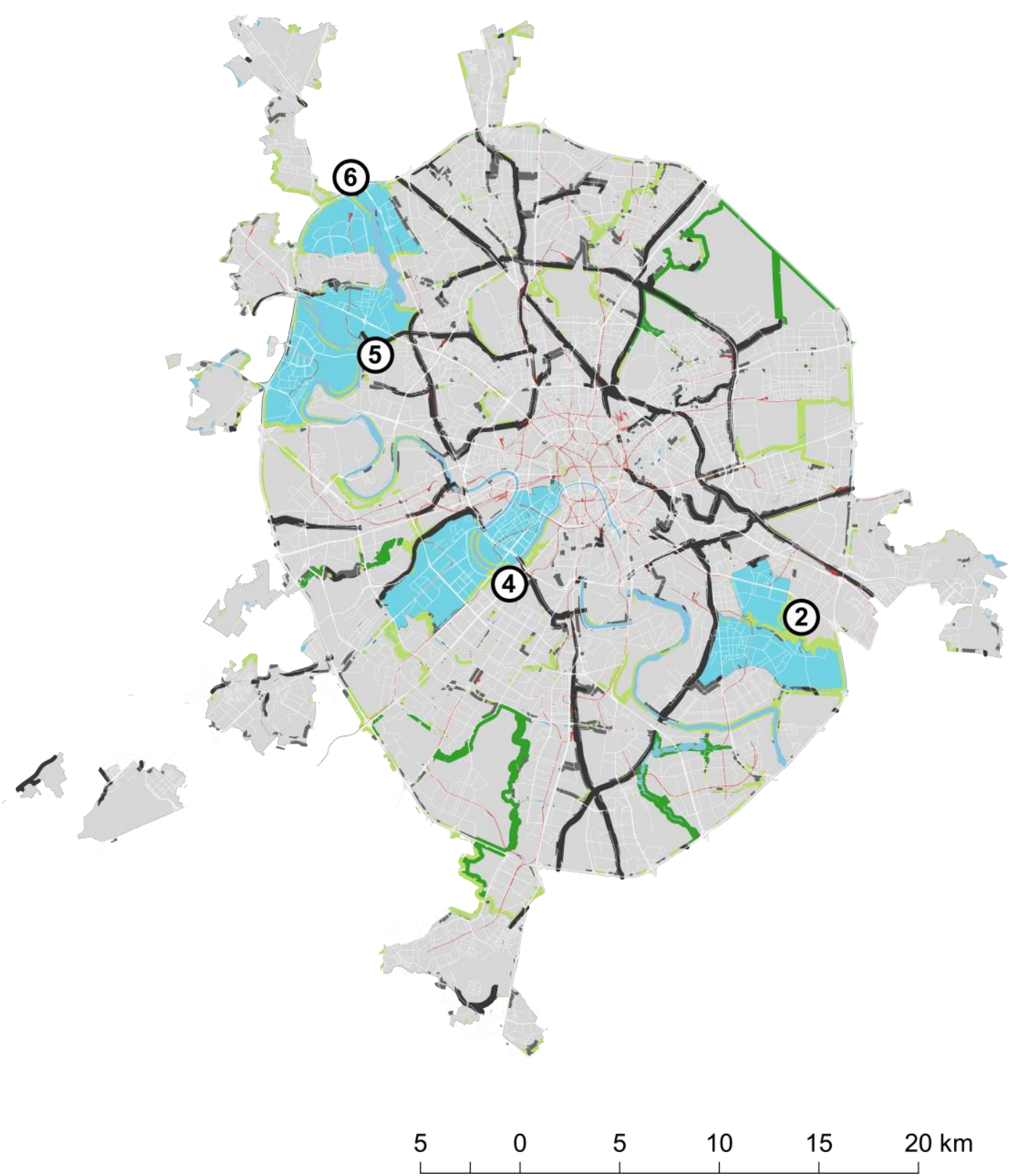

Figure 8. Final set. Author's calculations

We assume that the final sample we carried out is not sufficient, and there may be much more tracing variations connecting other areas. But we have responded the issue we posed at the beginning. Indeed, arguing in terms of throughput and spatial connectivity, we have shown the areas with the greatest potential for CPT. These pairs of districts are preferred to be connected better but on the other hand not by implementing above-ground solutions while underground facilities burden the city budget and as a result taxpayers. 


\section{References}

Alshalalfah B. et al. (2012) // Aerial Ropeway Transportation Systems in the Urban Environment: State of the Art [Journal] - (c) American Society of Civil Engineers: Journal of Transportation Engineering, Issue Number 3. Volume: 138

Blinkin Michael (2018) // E.G. Yasin Research Seminar "Urban mobility and spatial structure of the city: background, reality, forecasts". - Institute for Transport Economics and Transport Policy Studies, HSE

Carlet F. (2016) // "An Overview of Aerial Ropeway Transit and Its Potential in Urban Environments," in SBE16 Towards Post-Carbon Cities, 18-19 February 2016, TORINO, pp. 228-295

Dale S. et al. (2013) // The Essential Guide to Cable Cars, Urban Gondolas \& Cable Propelled Transit [Book]. - CUP, The Gondola Project Guide

Doppelmayr/Garaventa_1 (2018) // Reversible Aerial Tramway Brochure https://www.doppelmayr.com/en/products/reversible-aerialtramway/brochure/browsethe-brochure-67/

Ingrid E. Schneider (2013) // Quality of Life: Assessment for Transportation Performance Measures [report] - Minnesota Department of Transportation

Griškevičienė Daiva and Griškevičius Algirdas (2006) // The 6th International Conference "Reliability and Statistics In Transportation And Communication - 2006" [conference] // Sustainability of Vilnius Public Transport System by the Integration of All Modes of Passenger Conveyance. - 2006. - T. Session 3

Government of Moscow (2015) // "On approval of regional standards for urban planning in Moscow» October 1, 2015 N 945-PP

Jacobs MPO Final Report (2016) // Aerial Cable Transit Feasibility Study. - Miami

Madejski J. (2005) // Light rail, tram track and turnout geometry [article] // WIT Transactions on The Built Environment. - (C) WIT Press, Vol 77.

Marocchi Andrea (2015) // Cableways for Urban Transportation: History, State of the Art and Future Developments [report] - O.I.T.A.F.

Rosstat (2018) // Resident population on 1st of January 2018 and the average for 2017 [Online]. - Rosstat, 2018 -

http://www.gks.ru/free doc/new site/population/demo/Popul2018.xls

UN Revision of World Urbanization Prospects (2018) // United Nations. - The Population Division of the Department of Economic and Social Affairs, https://data.worldbank.org/indicator/sp.urb.totl.in.zs 


\section{Appendix}
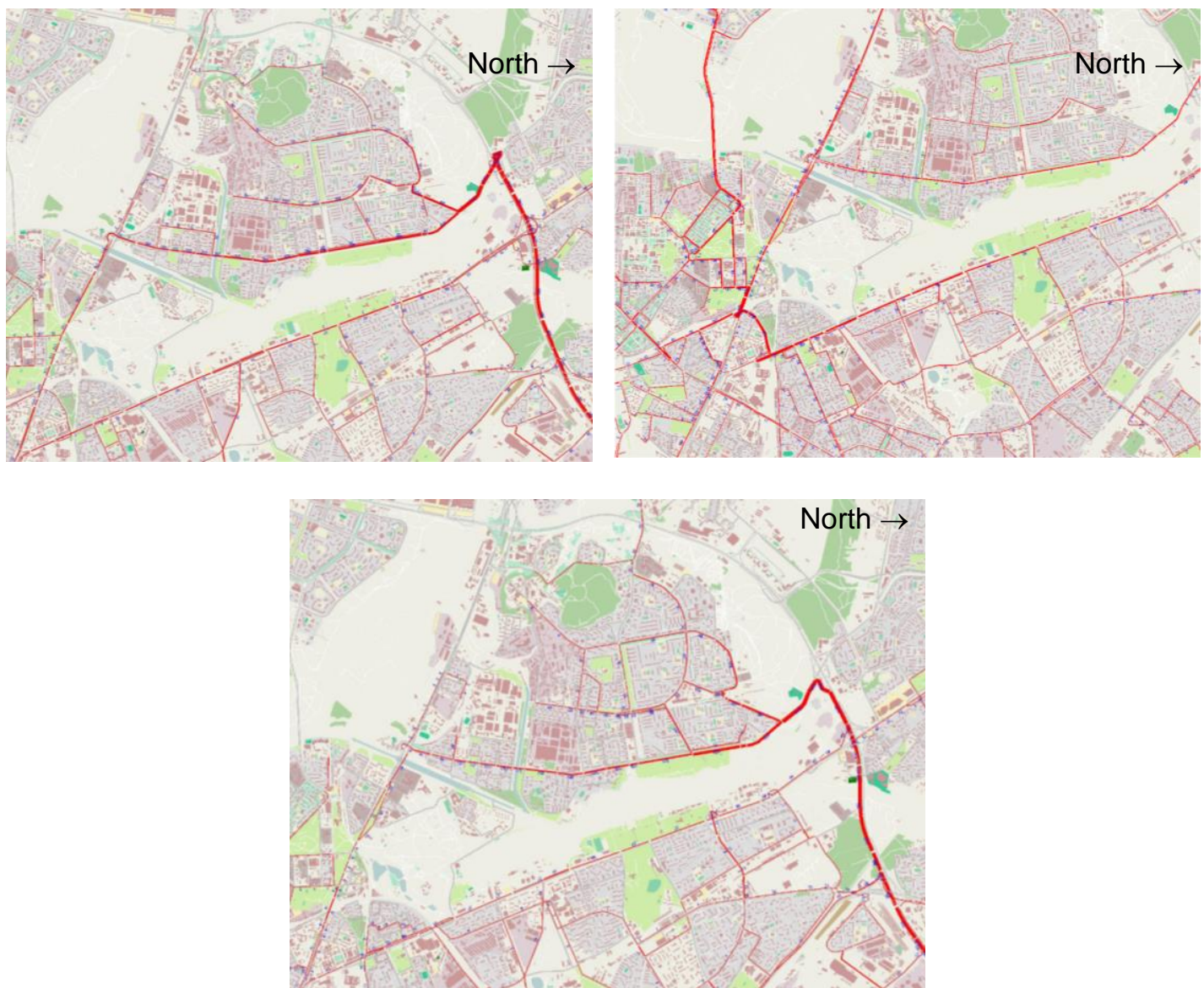

Link-analysis for Severnoe Tushino - Levoberezhniy 